\title{
PASCAOPERASI ADENOMA HIPOFISIS: HUBUNGAN ANTARA DURASI AWITAN DENGAN LUARAN KLINIS VISUS DAN LAPANG PANDANG
}

\author{
POST OPERATIVE PITUITARY ADENOMA PATIENTS : TIME ONSET AND ITS \\ CORRELATION WITH VISUAL ACUITY AND VISUAL FIELD OUTCOMES
}

\author{
Renindra Ananda Aman, * Reki Setiawan, * Retno Asti Werdhani, * Samsul Ashari, * David Tandian,
}

* Syaiful Ichwan, * Affan Priyambodo, * Setyo Widi Nugroho*

\section{ABSTRACT}

Introduction: Pituitary adenomas can cause decrease of visual acuity (VA) and narrowing visual field (VF). Several studies have showed that the duration of complaints were related significantly with clinical outcomes. As a national referral center hospital, all pituitary adenoma patients who came to our institution were referred from ophthalmologists, neurologists, and neurosurgeons from other institutions.

Aim: In this study, we investigated the relationship between duration, which is calculated from the time of symptoms first appeared to the time of surgery, and outcome (VA and VF) in pituitary adenoma patients who underwent transsphenoidal surgery.

Methods: A retrospective design was used on pituitary adenoma patients that underwent transsphenoidal surgery between 2015-2017 in Cipto Mangunkusumo Hospital. The duration between symptoms'onset and surgery was calculated in months.VA and VF examinations were performed 1 day before surgery and within 1 to 2 months postoperatively.

Results: There were 71 patients (36 male, 35 female) with decreased VA and narrowed VF, with a median age of 42 years (20-77 years). The median length of duration of onset for both symptoms was 12 months (1-108 months). 40.5\% patients had improved VA postoperatively, with median duration of onset of 11 months. Improvement in VF was experienced in $67.6 \%$ patients, with median duration of onset of 12 months.

Discussion: There was a statistically significant relationship between the duration of onset and the VF outcomes. Improvements in the VF were found in patients who underwent surgery up to 12 months after the time of onset.

Keywords: Pituitary adenoma, transsphenoidal surgery, visual acuity, visual field

\section{ABSTRAK}

Pendahuluan: Adenoma hipofisis dapat menyebabkan penurunan visus dan penyempitan lapangan pandang. Beberapa penelitian telah menunjukkan bahwa lama keluhan berhubungan secara signifikan dengan hasil klinis. Sebagai rumah sakit pusat rujukan nasional, semua pasien adenoma hipofisis yang datang ke RSUPN Dr. Cipto Mangunkusumo (RSCM) dirujuk dari dokter spesialis mata, ahli saraf, dan ahli bedah saraf dari institusi lain.

Tujuan: Dalam penelitian ini, kami meneliti hubungan antara durasi, yang dihitung dari saat gejala pertama kali muncul ke waktu operasi, dan hasil visus dan lapang pandang pada pasien adenoma hipofisis yang menjalani operasi transfenoidal.

Metode: Penelitian ini merupakan penelitian restrospektif pada pasien adenoma hipofisis yang menjalani operasi transsfenoidal antara 2015-2017 di RSCM. Durasi antara awitan gejala dan operasi dihitung dalam bulan. Pemeriksaan visus dan lapang pandang dilakukan 1 hari sebelum operasi dan dalam 1 hingga 2 bulan pascaoperasi.

Hasil: Terdapat 71 pasien (36 pria, 35 wanita) dengan penurunan visus dan lapang pandang menyempit, dengan usia rata-rata 42 tahun (20-77 tahun). Durasi rata-rata awitan untuk kedua gejala adalah 12 bulan (1-108 bulan). Sebanyak $40,5 \%$ pasien mengalami peningkatan visus pascaoperasi, dengan durasi rata-rata awitan 11 bulan. Peningkatan lapang pandang dialami pada $67,6 \%$ pasien, dengan durasi rata-rata awitan 12 bulan.

Diskusi: Kesimpulan penelitian terdapat hubungan bermakna secara statistik antara durasi awitan sampai dilakukan tindakan operasi dengan luaran klinis lapang pandang. Perbaikan lapang pandang didapatkan pada pasien yang memiliki durasi awitan sampai dilakukan tindakan operasi sampai dengan 12 bulan.

Kata kunci: Adenoma hipofisis, lapang pandang, operasi transfenoidal, visus

*Departemen Bedah Saraf FK Universitas Indonesia/RSUPN Dr. Cipto Mangunkusumo, Jakarta, Indonesia. Korespondensi: rajohnwien@gmail.com.

\section{PENDAHULUAN}

Berdasarkan pengalaman Departemen Bedah Saraf Fakultas Kedokteran Universitas Indonesia/ RSUPN Dr. Cipto Mangunkusumo (FKUI/RSCM), pasien datang berobat dengan durasi keluhan yang beragam untuk suatu diagnosis adenoma hipofisis. Sebagai rumah sakit pusat rujukan nasional, semua pasien adenoma hipofisis yang datang ke institusi 
kami merupakan pasien rujukan dari dokter spesialis mata, spesialis saraf, maupun dokter spesialis bedah saraf dari institusi lain. Pada penelitian sebelumnya, pasien dengan tumor regio sella termasuk tumor hipofisis yang dilakukan tindakan operasi di RSCM selama tahun 2014-2016 dengan lama keluhan yang bervariasi yaitu antara 4 bulan sampai 10,25 tahun (123 bulan) dengan median 12 bulan. ${ }^{1}$ Hal ini disebabkan oleh salah satunya adalah pengetahuan dan kesadaran pasien terhadap penyakit yang dideritanya masih rendah.

Adenoma hipofisis dapat menyebabkan keluhan visus, lapang pandang, dan keluhan-keluhan lain yang diakibatkan oleh gangguan hormonal. ${ }^{2} \mathrm{Pada}$ pasien dengan makroadenoma hipofisis, semakin awal dilakukan tindakan operasi, maka luaran klinis yang didapatkan akan semakin baik terhadap visus dan lapang pandang. ${ }^{3}$ Beberapa penelitian juga telah menyatakan hubungan antara durasi keluhan dengan luaran klinis dengan hasil yang signifikan. ${ }^{4-8}$ Pada penelitian ini akan dicari hubungan antara durasi, yang dihitung mulai dari awal keluhan sampai dilakukan tindakan operasi, dengan luaran visus dan lapang pandang pada pasien adenoma hipofisis yang dilakukan operasi dengan pendekatan transnasal transfenoid. Dengan informasi tersebut kita dapat memberikan edukasi kepada pasien tentang penyakit yang dideritanya.

\section{TUJUAN}

Meneliti hubungan antara durasi, yang dihitung dari saat gejala pertama kali muncul ke waktu operasi, dan hasil visus dan lapang pandang pada pasien adenoma hipofisis yang menjalani operasi transfenoidal.

\section{METODE}

Penelitian ini merupakan studi restrospektif, deskriptif dan analitik pada pasien adenoma hipofisis yang dilakukan tindakan operasi dengan pendekatan transnasal transfenoid antara tahun 2015-2017. Selama tahun 2015-2017 terdapat 92 tindakan operasi transfenoid dari 90 pasien dengan hasil patologi anatomi adenoma hipofisis, karena terdapat dua pasien yang menjalani operasi sebanyak 2 kali. Data yang diambil untuk penelitian ini adalan operasi yang pertama kali dilakukan. Empat pasien tidak terdapat keluhan visus dan lapang pandang tidak disertakan dalam penelitian. Lima belas pasien dieksklusi karena catatan variabel pada rekam medis yang tidak lengkap atau tidak ditemukan. Sehingga didapatkan 71 pasien yang memenuhi kriteria inklusi. Seluruh operasi dilakukan oleh spesialis bedah saraf dengan metode operasi yang sama dan masih digunakan hingga saat ini di RSCM. Semua pasien pada penelitian ini mengalami penurunan visus dan penyempitan lapang pandang. Durasi antara awitan sampai dengan dilakukan tindakan operasi dihitung dalam satuan bulan. Pemeriksaan visus dan lapang pandang dilakukan oleh peserta program pendidikan dokter spesialis bedah saraf tahap mandiri yang diverifikasi oleh dokter penanggung jawab pelayanan. Durasi ini dihitung dari waktu awal pasien mengalami keluhan penyempitan lapang pandang atau penurunan visus, sampai 1 hari sebelum dilakukan tindakan operasi. Dilakukan pemeriksaan visus dan lapang pandang 1 hari sebelum operasi dan dalam 1 sampai 2 bulan pascaoperasi. Pada penelitian ini digunakan uji statistik nonparametrik Mann-Whitney karena distribusi data tidak normal (Kolmogorov-Smirnov test $<0,05$ ).

Pada penelitian ini juga dihitung volume tumor, presentase tumor yang diambil, dan perluasan tumor. Untuk volume tumor dihitung dengan cara mengambil data ukuran panjang, lebar, dan tinggi tumor dari ekspertise radiologi, lalu dihitung dengan menggunakan rumus elips yaitu panjang $\mathrm{x}$ lebar $\mathrm{x}$ tinggi $x$ 0,52. Untuk presentase tumor yang diambil ditentukan dengan cara menghitung selisih tumor sebelum dan sesudah operasi dari pencitraan pre dan pascaoperasi. Untuk perluasan tumor ditentukan dengan menggunakan skala Hardy. Perluasan ke sisterna suprasella saja diklasifikasikan sebagai stage A, jika sampai ke dasar dari ventrikel III makan diklasifikasikan sebagai stage B. Jika sudah sampai ke ventrikel III disebut sebagai stage C. Tumor yang meluas ke lateral intradura atau ekstradura diklasifikasikan sebagai stage $\mathrm{D}$ dan stage $\mathrm{E}$.

Seluruh pasien dilakukan pemeriksaan visus dan lapang pandang di ruang rawat inap 1 hari 
sebelum dilakukan tindakan operasi. Pemeriksaan visus dilakukan dengan cara hitung jari bedside. Dikatakan visus menurun jika pada pemeriksaan hitung jari didapatkan hasil kurang dari 6/60. Untuk pemeriksaan lapang pandang dilakukan pemeriksaan tes konfrontasi. Dikatakan lapang pandang menyempit jika lapang pandang pasien kurang dari lapang pandang pemeriksa. Visus dan lapang pascaoperasi dilakukan pemeriksaan saat pasien kontrol ke poliklinik dalam masa 1-2 bulan pascaoperasi dengan metode pemeriksaan yang sama dengan preoperasi. Penelitian memperoleh surat keterangan layak etik dari institusi.

\section{HASIL}

Sembilan puluh dua pasien adenoma hipofisis selama tahun 2015-2017, 71 pasien masuk kriteria inklusi. Median usia pasien adalah 42 tahun (2077 tahun). Terdapat 36 pasien laki-laki $(50,7 \%)$ dan 35 pasien perempuan (49,3\%). Seluruh pasien pada penelitian ini mengalami penurunan visus dan penyempitan lapang pandang. Pada penelitian kami didapatkan median volume tumor preoperasi adalah $12.56 \mathrm{cc}$ dengan volume terkecil $0,98 \mathrm{cc}$ dan volume terbesar $230,23 \mathrm{cc}$. Presentase tumor yang diambil didapatkan median $43,3 \%$ dengan presentase terkecil 5,1\% dan presentase terbesar 100 (Tabel 1).

Seluruh pasien pada penelitian kami mengalami keluhan penurunan visus dan penyempitan lapang

Tabel 1. Karakteristik Demografi $(n=71)$

\begin{tabular}{lc}
\hline \multicolumn{1}{c}{ Variabel } & n (\%) \\
\hline Usia (tahun), Median (Min-maks) & $42(20-77)$ \\
Jenis Kelamin & $36(50,7)$ \\
- Laki-laki & $35(49,3)$ \\
- Perempuan & $12,56(0,98-230,23)$ \\
Volume Tumor Preoperasi (cc), & \\
Median (Min-maks) & $43,3(5,1-100)$ \\
Presentase Tumor yang Diambil (\%), & \\
Median (Min-maks) & $46(64,7)$ \\
Daerah Asal & $35(35,3)$ \\
- Jabodetabek & \\
- Luar Jabodetabek & \\
Pembiayaan & $65(91,5)$ \\
- BPJS & $6(8,5)$ \\
\hline BPJS: Baransi swasta/umum &
\end{tabular}

pandang sebelum operasi (Tabel 2). Pasien dinyatakan visusnya menurun jika didapatkan kurang dari 6/60 pada tes hitung jari bedside. Pasien dinyatakan lapang pandangnya menyempit jika lapang pandang lebih sempit dari pemeriksa pada pemeriksaan konfrontasi. Setelah operasi, pasien dengan keluhan penurunan visus didapatkan perbaikan visus pada 50 pasien $(70,4 \%)$, sedangkan pada keluhan penyempitan lapang pandang didapatkan perbaikan pada 48 pasien $(67,6 \%)$. Median awitan dari keluhan tidak perbaikan adalah 12 bulan ( $\mathrm{p}=0,58$; MannWhitney U test) (Tabel 3). Untuk median awitan keluhan lapang pandang perbaikan adalah 12 bulan, dan lapang pandang yang tidak perbaikan adalah 24 bulan ( $\mathrm{p}=0,01$ Mann-Whitney U test).

Untuk keluhan visus, pada kelompok volume tumor terdapat sedikit perbedaan pada kelompok visus perbaikan dan tidak perbaikan. Pada persentase tumor yang diambil, untuk visus perbaikan lebih banyak pada tumor yang diambil dibandingkan dengan visus tidak perbaikan. Pada penelitian kami, didapatkan median volume tumor preoperasi adalah $12,56 \mathrm{cc}$ dengan volume terkecil $0,98 \mathrm{cc}$ dan volume terbesar 230,23cc. Volume tumor preoperasi pada pasien dengan visus perbaikan dan tidak perbaikan adalah $12,4 \mathrm{cc}$ dan $12,64 \mathrm{cc}$ secara berurutan. Volume tumor preoperasi pada pasien dengan lapang pandang perbaikan dan tidak perbaikan adalah $12,17 \mathrm{cc}$ dan visus yang perbaikan adalah 11 bulan, dan visus yang

BPJS: Badan Penyelenggara Jaminan Sosial. 
Tabel 2. Karakteristik Pasien Sebelum Operasi $(n=71)$

\begin{tabular}{lcc}
\multicolumn{1}{c}{ Variabel } & Median & Min-maks \\
\hline Durasi Mulai Keluhan Visus Sampai Dengan Operasi (bulan) & 12 & $1-108$ \\
$\begin{array}{l}\text { Durasi Mulai Keluhan Lapang Pandang Sampai Dengan } \\
\text { Operasi (bulan) }\end{array}$ & 12 & $1-108$ \\
\hline
\end{tabular}

Tabel 3. Karakteristik Pasien Setelah Operasi $(n=71)$

\begin{tabular}{lcc}
\hline \multicolumn{1}{c}{ Variabel } & Tidak Perbaikan & Perbaikan \\
n (\%) & n & (\%) \\
\hline Visus & $21(29,6)$ & $50(70,4)$ \\
$\begin{array}{l}\text { Durasi Awitan Visus (tahun), } \\
\text { Median (Min-maks) }\end{array}$ & $12(1-108)$ & $11(1-72)$ \\
Lapang Pandang & $23(32,4)$ & $48(67,6)$ \\
$\begin{array}{l}\text { Durasi Awitan Lapang Pandang (bulan), } \\
\text { Median (Min-maks) }\end{array}$ & $24(2-108)$ & $12(1-72)$ \\
\hline
\end{tabular}

$12,85 \mathrm{cc}$ secara berurutan. Pada visus perbaikan didapatkan sebanyak $47,9 \%$ tumor terambil, dan pada visus tidak perbaikan didapatkan 31,9\% tumor yang terambil. Pada kelompok perluasan tumor, untuk visus perbaikan lebih banyak didapatkan pada hardy $\geq 2 \mathrm{C}$ (Tabel 4).

Untuk keluhan lapang pandang, pada kelompok volume tumor, terdapat sedikit perbedaan pada lapang pandang perbaikan dan tidak perbaikan. Pada presentase tumor yang diambil, untuk lapang pandang perbaikan lebih banyak tumor yang diambil dibandingkan dengan lapang pandang tidak perbaikan. Pada keluhan lapang pandang perbaikan, didapatkan 49,2\% tumor yang terambil, dan pada lapang pandang yang tidak perbaikan didapatkan $28,26 \%$ tumor yang terambil. Pada kelompok perluasan tumor, untuk lapang pandang perbaikan lebih banyak didapatkan pada hardy $\geq 2$ (Tabel 5). Untuk volume tumor, presentase tumor yang diambil, dan perluasan tumor, juga tidak dapat diuji secara

Tabel 4. Karakteristik Pasien Setelah Operasi $(n=71)$

\begin{tabular}{lccc}
\hline \multicolumn{1}{c}{ Variabel } & Visus Tidak Perbaikan & Visus Perbaikan & p* \\
\hline Durasi (bulan) & $12(1-108)$ & $11(1-72)$ & 0,586 \\
$\begin{array}{l}\text { Volume Tumor Preoperasi (cc), } \\
\text { Median (Min-maks) }\end{array}$ & $12,64(0,98-112,26)$ & $12,40(1,52-230,23)$ \\
$\begin{array}{l}\text { Presentase Tumor yang Diambil (\%), } \\
\text { Median (Min-maks) }\end{array}$ & $31,9(5,88-100)$ & $47,93(5,15-100)$ \\
$\begin{array}{l}\text { Perluasan Tumor, n(\%) } \\
\text { - Hardy } \leq 2 \mathrm{~B}\end{array}$ & $6(37,5)$ & $10(62,5)$ \\
- Hardy $\geq 2 \mathrm{C}$ & $15(27,3)$ & $40(72,7)$ \\
\hline
\end{tabular}

"Uji Mann-Whitney. statistik karena dibutuhkan jumlah sampel yang lebih banyak.

\section{PEMBAHASAN}

Adenoma hipofisis merupakan tumor jinak dengan prevalensi $10-20 \%$ dari seluruh tumor otak primer. ${ }^{9}$ Adenoma hipofisis dapat menimbulkan gejala yang diakibatkan oleh penekanan tumor pada struktur yang berada disekitar hipofisis tersebut. Gejala tersebut dapat berupa gangguan penglihatan terutama gangguan lapang pandang yang dapat disertai dengan turunnya tajam penglihatan, serta keluhan lainnya seperti pandangan ganda dan nyeri kepala. ${ }^{10}$

Pada penelitian ini seluruh pasien mengalami keluhan penurunan tajam penglihatan dan penyempitan lapang pandang. Pada penelitian ini durasi untuk keluhan visus dan lapang pandang adalah sama yaitu dengan median 12 bulan (1-108 bulan). Pada penelitian ini dilakukan evaluasi visus pada 1 sampai 2 bulan pascaoperasi saat pasien 
Tabel 5. Karakteristik Pasien Setelah Operasi $(n=71)$

\begin{tabular}{|c|c|c|c|}
\hline Variabel & $\begin{array}{c}\text { Lapang Pandang Tidak Per- } \\
\text { baikan }\end{array}$ & $\begin{array}{c}\text { Lapang Pandang Per- } \\
\text { baikan }\end{array}$ & $\mathbf{p}^{*}$ \\
\hline Durasi (bulan) & $24(2-108)$ & $12(1-72)$ & 0,012 \\
\hline $\begin{array}{l}\text { Volume Tumor Preoperasi (cc), } \\
\text { Median (Min-maks) }\end{array}$ & $12,85(0,98-112,26)$ & $12,17(1,52-230,23)$ & \\
\hline $\begin{array}{l}\text { Presentase Tumor yang Diambil (\%), } \\
\text { Median (Min-maks) }\end{array}$ & $28,26(5,88-91,4)$ & $49,2(45,15-100)$ & \\
\hline $\begin{array}{l}\text { Perluasan Tumor, } \mathbf{n}(\%) \\
\text { - } \quad \text { Hardy } \leq 2 \mathrm{~B} \\
\text { - } \quad \text { Hardy } \geq 2 \mathrm{C}\end{array}$ & $\begin{array}{c}6(37,5) \\
17(32,4)\end{array}$ & $\begin{array}{l}10(62,5) \\
38(69,1)\end{array}$ & \\
\hline
\end{tabular}

kontrol ke poliklinik. Sebuah literatur mengatakan bahwa perbaikan penglihatan pascaoperasi terjadi dalam tiga tahapan. Tahap pertama adalah tahapan perbaikan secara cepat yang berlangsung dalam hitungan menit hingga beberapa hari pascaoperasi. Tahap kedua adalah tahapan perbaikan secara lambat yang berlangsung dalam hitungan minggu sampai satu bulan. Pada tahap lanjut, perbaikan visus berlangsung dalam hitungan bulan hingga beberapa tahun setelah operasi. ${ }^{5}$ Berdasarkan pada satu studi dikatakan bahwa pada masa 1 sampai 4 bulan pascaoperasi adalah periode dimana perbaikan visus terlihat nyata. ${ }^{11}$

Pada penelitian lain dikatakan bahwa luaran klinis lapang pandang pascaoperasi akan lebih menjanjikan bila keluhan lapang pandang hanya terjadi pada salah satu mata saja. ${ }^{10}$ Benjamin dkk menyatakan bahwa perbaikan visus terjadi dengan jangka waktu yang bervariasi. Perbaikan yang banyak terjadi adalah pada periode tiga sampai enam bulan pascaoperasi. ${ }^{5}$

Pada penelitian lain juga dikatakan bahwa salah satu faktor pre operatif yaitu durasi awitan keluhan penglihatan merupakan prediktor untuk luaran pascaoperasi. ${ }^{5}$ Pada penelitian lain juga memasukkan durasi sebagai faktor yang berpengaruh pada perbaikan lapang pandang dengan durasi keluhan lapang perbaikan adalah 10,8 bulan. ${ }^{4}$ Pada satu penelitian didapatkan bahwa pada durasi keluhan penglihatan yang kurang dari 6 bulan, didapatkan luaran klinis yang lebih baik dibandingkan pasien dengan durasi lebih dari 6 bulan. ${ }^{12}$ Thotakura dkk. menyimpulkan bahwa pasien dengan keluhan visus kurang dari 1 tahun memiliki luaran klinis yang baik $(\mathrm{p}=0,01) .{ }^{6}$ Penelitian lain mengatakan bahwa kebutaan berhubungan dengan pemanjangan durasi dari gejala. ${ }^{8}$

Perbaikan visus dan lapang pandang pada kompresi kiasma akibat adenoma hipofisis dapat terjadi segera setelah dilakukan dekompresi. Pada beberapa kasus perbaikan visus dan lapang pandang sudah ditemukan hari pertama sampai kedua pascaoperasi. ${ }^{13}$ Pada satu penelitian dikatakan bahwa perbaikan penglihatan dimulai pada hari kedua pascaoperasi dan akan terus berlanjut sampai setidaknya satu tahun pascaoperasi. ${ }^{14}$

Penekanan pada saraf optik pada awalnya menyebabkan blokade dari konduksi aksonal yang mana bersifat reversibel. ${ }^{15}$ Setelah dilakukan dekompresi, serabut saraf yang mengalami iskemia kronis dan yang mengalami demielinisasi sebagian, memiliki potensi untuk pulih dan meningkatkan fungsinya, tetapi hanya pada kasus yang mana pada serabut saraf tersebut dapat mempertahankan potensi pemulihan biologis signifikannya. ${ }^{16}$ Terdapat sebuah penelitian yang dilakukan oleh Clifford-jones dkk. dimana pada penelitian ini dilakukan percobaan untuk menentukan saat terjadinya proses demielinisasi dan remielinisasi pada saraf kranial yang dilakukan penekanan pada saraf optik kucing. Pada penelitian ini didapatkan bahwa demielinisasi dimulai pada hari kedua setelah terjadinya penekanan pada saraf dan remielinisasi dengan ketebalan jaringan saraf yang abnormal baru terbentuk selama beberapa minggu hingga 19 minggu setelah terjadinya penekanan pada saraf tersebut. ${ }^{17,18}$ Proses remielinisasi inilah yang dapat menjelaskan terjadinya pemulihan penglihatan setelah dilakukan dekompresi pada saraf, bahkan 
pada pasien yang mengalami peneknanan saraf dalam jangka waktu yang lama sekalipun. ${ }^{18}$

Penjelasan yang diajukan untuk perbaikan fungsi saraf secara dini adalah menghilangkan blokade dari konduksinya dan atau perbaikan dari sitoskeleton. Fase perbaikan lanjut telah dijelaskan dengan proses remielinisasi yang didukung oleh studi pada kucing. Penekanan kronis pada saraf optik kucing telah terbukti menyebabkan terjadinya demielinisasi bertahap dalam kombinasi dengan aksotomi parsial. Cottee dkk. juga memantau konduksi saraf setelah dilakukan dekompresi dengan menggunakan elektroda dan dapat mengamati fase cepat maupun lambat dari fase pemulihan. Analisis mikroskopik menunjukan remielinasi yang sesuai dengan perjalanan dari fase penyembuhan akhir. Tidak ada perbaikan dari akson yang sudah mengalami aksotomi. ${ }^{11}$

Kompresi kronis pada kiasma akan menyebabakan atrofi optik sekunder yang ditandai dengan penipisan lapisan serabut saraf retina (LSSR). Danesh-Meyer dkk. menunjukkan hubungan ketebalan LSSR sebelum operasi dengan perbaikan fungsi visual pascaoperasi. ${ }^{19}$ Pada pasien dengan LSSR normal preoperasi, 97,5\% mencapai visus 6/12 atau lebih baik diatas satu tahun pascaoperasi dibandingkan $88,2 \%$ pada pasien dengan penipisan LSSR, 73,4\% dengan LSSR normal mencapai visus 6/6 atau lebih baik dibandingkan dengan 67,6\% pada pasien dengan penipisan LSSR. Pada pasien dengan LSSR normal perbaikan visus mencapai nilai 6/6 dalam jangka waktu 6-10 minggu pascaoperasi. Pada pasien dengan LSSR normal perbaikan lapang pandang juga mencapai nilai yang lebih baik dibandingkan dengan pasien dengan penipisan LSSR. Perbaikan lapang pandang yang signifikan ditemukan pada periode 6-10 minggu hingga 9-10 bulan pascaoperasi. ${ }^{19}$

Tingkat kecepatan pemulihan fungsi visual dipengaruhi oleh jarak awitan terjadinya gangguan fungsi visual hingga waktu operasi. Durasi gejala yang lebih pendek berhubungan dengan perbaikan fungsi visual pada fase awal setelah operasi. Pada pasien dengan durasi gejala dibawah 6 bulan, $33,2 \%$ menunjukkan perbaikan visus segera pascaoperasi. Pada periode yang sama hanya $1,4 \%$ dari pasien dengan gejala di atas satu tahun menunjukan hasil serupa. ${ }^{13}$ Anik dkk. juga menunjukkan hubungan serupa antara durasi gejala dan kecepatan perbaikan fungsi visual, hal ini diduga berhubungan dengan tingkat remielinisasi yang terjadi pada fase awal pemulihan fungsi visual. ${ }^{20}$

Perbaikan fungsi visual setelah dekompresi dihubungkan dengan usia yang lebih muda, durasi gejala yang lebih singkat dan derajat penurunan fungsi visual preoperatif yang lebih baik. ${ }^{21}$ Pada peneltian ini usia tidak dihitung. Selain itu, ketebalan lapisan serabut saraf retina peripapiler juga berpengaruh dalam perbaikan fungsi visual setelah dilakukan dekompresi. Penurunan ketebalan lapisan serabut saraf retina peripapiler preoperatif menunjukkan pengembalian lapang pandang yang lebih lambat dibandingkan dengan ketebalan lapisan serabut saraf retina perpapiler yang normal. ${ }^{21}$

Keluhan nyeri kepala didapatkan pada 31 pasien (43\%). Tumor jenis ini insidensinya meningkat dengan bertambahnya usia. Pada penelitian ini usia pasien bervariasi dengan median 42 tahun (20-77 tahun). Pada satu penelitian didapatkan bahwa tidak terdapat hubungan antara konsistensi tumor dan usia pasien. $^{22}$

Keterbatasan pada penelitian ini adalah tidak dapat dilakukan penilaian visus dan lapang pandang secara objektif karena data rekam medis yang tidak lengkap untuk visus dan lapang pandang. Penelitian ini juga bersifat restrospektif. Untuk menilai variabel lain misalnya volume tumor, presentase tumor yang diambil, serta perluasan tumor, diperlukan sampel yang lebih besar. Sabagai saran, perlu dilakukan penelitian prospektif untuk menilai variabel-variabel tersebut. Pada penelitian selanjutnya juga dapat dilakukan dengan menilai visual impairment score (VIS).

\section{KESIMPULAN}

Terdapat hubungan bermakna antara durasi awitan sampai dilakukan tindakan operasi dengan luaran klinis lapang pandang. Perbaikan lapang pandang didapatkan pada pasien yang memiliki 
durasi awitan sampai dilakukan tindakan operasi sampai dengan 12 bulan.

\section{DAFTAR PUSTAKA}

1. Gunawan K, Saekhu M, Aman RA, Ichwan S, Tobing $\mathrm{HG}$, Ashari S. Visual function impairment in sellar region tumors: an initial study. Advanced Science Letters. 2017;23(7):6743-47.

2. Azmeh A. Neuro-ophthalmology findings in pituitary disease (review of literature). Pituit Dis. 2018;2018:77065.

3. Ho RW, Huang HM, Ho JT. The influence of pituitary adenoma size on vision and visual outcomes after trans-sphenoidal adenectomy: a report of 78 cases. J Korean Neurosurg Soc. 2015;57(1):23-31.

4. Yu FF, Chen LL, Su YH, Huo LH, Lin XX, Liao RD. Factors influencing improvement of visual field after trans-sphenoidal resection of pituitary macroadenomas: A retrospective cohort study. Int J Ophthalmol. 2015;8(6):1224-8.

5. Uy B, Wilson B, Kim WJ, Prashant G, Bergsneider M. Vi s ua 1 outcomes after pituitary surgery. Neurosurg Clin N Am. 2019;30(4):483-9.

6. Thotakura A, Patibandla M, Panigrahi M, Addagada G. Predictors of visual outcome with transsphenoidal excision of pituitary adenomas having suprasellar extension: a prospective series of 100 cases and brief review of the literature. Asian J Neurosurg. 2017;12(1):1.

7. Muskens IS, Zamanipoor AH, Vanessa N, Lamba N, Senders JT, Van-Furth WR, dkk. Visual outcomes after endoscopic endonasal pituitary adenoma resection: a systematic review and meta-analysis. Pituitary. 2017;20(5):532-52.

8. Tagoe NN, Essuman VA, Bankah P, Dakurah T, Hewlett VK, Akpalu J, dkk Visual outcome of patients with pituitary adenomas following surgery and its contributory factors at a tertiary hospital in Ghana. Ethiop J Health Sci. 2019;29(1):895-902.

9. Syro LV, Rotondo F, Ramirez A, Di-leva A, Sav MA, Restrepo LM, dkk. Progress in the diagnosis and classification of pituitary adenomas. Front Endocrinol (Lausanne). 2015;6:1-8.

10. Lee DK, Sung MS, Park SW. Factors influencing visual field recovery after transsphenoidal resection of a pituitary adenoma. Korean J Ophthalmol. 2018;32(6):488.

11. Lilja Y, Gustafsson O, Ljungberg M, Starck G, Lindblom B, Skoglund T, dkk. Visual pathway impairment by pituitary adenomas: quantitative diagnostics by diffusion tensor imaging. J Neurosurg. 2017;127(3):569-79.
12. Vasani HH, Chauhan VM, Bharoliya M, Patel KB, Shah JK. Visual outcomes and factors affecting the outcome after transsphenoidal excision of pituitary macroadenoma. ASOL. 2019;1(2):17-21.

13. Dutta P, Gyurmey T, Bansal R, Phatak A, Dhandapani S, Rai A, dkk. Visual outcome in 2000 eyes following microscopic transsphenoidal surgery for pituitary adenomas: protracted blindness should not be a deterrent. Neurol India. 2016;64(6):1247-53.

14. Luomaranta T, Raappana A, Saarela V, Liinamaa MJ. Factors affecting the visual outcome of pituitary adenoma patients treated with endoscopic transsphenoidal surgery. World Neurosurg. 2017;105:422-31.

15. Sundaram ANE, Abhayambika A, Kumar S. Bilateral compressive optic neuropathy from renal osteodystrophy caused by branchio-oto-renal syndrome stabilised after parathyroidectomy. NeuroOphthalmol. 2017;41(6):321-5.

16. Grkovic D, Davidovic S. Prognostic factors for postoperative visual outcome in surgically treated suprasellar meningiomas. Med Pregl. 2016;69(56): $146-52$

17. Lutz J, Thon N, Stahl R, Lummel N, Tonn JC, Linn $\mathrm{J}$, dkk. Microstructural alterations in trigeminal neuralgia determined by diffusion tensor imaging are independent of symptom duration, severity, and type of neurovascular conflict. J Neurosurg. 2016;124(3):823-30.

18. Lee JM, Au M. Onodi cell mucocele: Case report and review of the literature. Ear, Nose Throat J. 2016;95(9):E4.

19. Danesh-Meyer HV, Wong A, Papchenko T, Matheos K, Stylli S, Nichols A, dkk. Optical coherence tomography predicts visual outcome for pituitary tumors. J Clin Neurosci. 2015;22(7):1098-104.

20. Anik I, Anik Y, Cabuk B, Caklili M, Pirhan D, Ozturk O, dkk. Visual outcome of an endoscopic endonasal transsphenoidal approach in pituitary macroadenomas: quantitative assessment with diffusion tensor imaging early and long-term results. World Neurosurg. 2018;112:e691-e701.

21. Sun M, Zhang ZQ, Ma CY, Chen SH, Chen XJ. Predictive factors of visual function recovery after pituitary adenoma resection: A literature review and meta-analysis. Int J Ophthalmol. 2017;10(11):174250.

22. Yiping L, Ji X, Daoying G, Bo Y. Prediction of the consistency of pituitary adenoma: a comparative study on diffusion-weighted imaging and pathological results. J Neuroradiol. 2016;43(3):186-94. 